\title{
Perspectives and Problems of Using Renewable Energy Sources and Implementation of Local "Green" Initiatives: A Regional Assessment
}

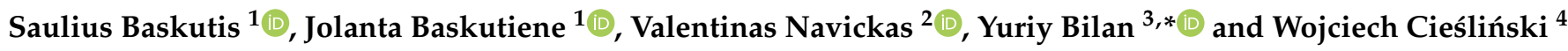 \\ 1 Department of Production Engineering, Faculty of Mechanical Engineering and Design, Kaunas University of \\ Technology, Studentu Str. 56, 51424 Kaunas, Lithuania; saubask@ktu.lt (S.B.); jbask@ktu.lt (J.B.) \\ 2 School of Economics and Business, Kaunas University of Technology, Gedimino Str. 50, \\ 44239 Kaunas, Lithuania; valentinas.navickas@ktu.lt \\ 3 Faculty of Management, Rzeszów University of Technology, Powstańców Warszawy al. 10, \\ 35-959 Rzeszów, Poland \\ 4 Department of Communication and Management, University School of Physical Education in Wrocław, \\ I. J. Paderewskiego Str. 35, 51-612 Wrocław, Poland; wojciech.cieslinski@awf.wroc.pl \\ * Correspondence: y.bilan@prz.edu.pl
}

Citation: Baskutis, S.; Baskutiene, J.; Navickas, V.; Bilan, Y.; Cieśliński, W. Perspectives and Problems of Using Renewable Energy Sources and Implementation of Local "Green" Initiatives: A Regional Assessment. Energies 2021, 14, 5888. https:// doi.org/10.3390/en14185888

Received: 25 August 2021

Accepted: 13 September 2021

Published: 17 September 2021

Publisher's Note: MDPI stays neutral with regard to jurisdictional claims in published maps and institutional affiliations.

Copyright: (c) 2021 by the authors. Licensee MDPI, Basel, Switzerland. This article is an open access article distributed under the terms and conditions of the Creative Commons Attribution (CC BY) license (https:// creativecommons.org/licenses/by/ $4.0 /)$.

\begin{abstract}
Environmental pollution, energy supply and security of supply have become major issues across the world due to climate change, limited energy sources, energy price volatility and energy supply constraints. Energy availability, energy efficiency and the replacement of fossil fuels by renewable energy sources are key factors in the global development of sustainable energy. In many countries with limited fossil fuel resources, the sustainable development of renewable energy sources is an important tool in reducing dependence on imported fuels. Some alternative energy sources, such as wind, solar, tidal and hydropower, seem almost inexhaustible. With the exception of tidal energy, all of these sources have been used extensively and for a long time. This article examines the improvement of energy security and the government's actions to promote the use of renewable energy sources, focusing on increasing energy efficiency and reducing energy intensity and dependence on energy imports in Lithuania. In addition, the article provides the state of renewable energy sources in Lithuania, aspects of sustainability and future development directions and perspectives.
\end{abstract}

Keywords: renewable energy; energy efficiency; greenhouse gas emissions

\section{Introduction}

After the closure of the Ignalina (Lithuania) nuclear power plant (NPP), producing electricity at a competitive price in Lithuania became problematic. In 31 December 2009, the second reactor of the Ignalina NPP was shut down and Lithuania switched from being a net exporter to being a net importer of electricity. Currently, Lithuania imports about 70\% electricity. Only the electricity produced at Kaunas hydroelectric power plant remained competitive. Nevertheless, further large and small hydropower plants development in Lithuania is not expected, as hydropower in Lithuania is neither economically nor environmentally promising. Unfortunately, the cost of electricity produced by all other power plants operating in Lithuania exceeds the market price. In this context, the expansion of the use of renewable energy sources is one of the key factors in the development of sustainable energy. In addition, the European Union aims to get at least $32 \%$ of its energy from renewable sources by 2030, leaving Member States free to set their own national renewable energy target. The Lithuanian National Energy Independence Strategy sets ambitious goals for the development of renewable energy for the future, as it is desired that at least $80 \%$ of renewable energy in final consumption and use of $100 \%$ of renewable electricity by 2050 [1]. 
Many countries in the world with limited fossil fuel resources are moving in this direction. The analysis carried out in the case of Japan showed that the most primary energy sources in Japan are biofuels and waste energy, followed by hydropower and geothermal energy [2,3]. Recently, China has focused on the photovoltaic, wind power and biomass industries. According to 2018 data, $97 \%$ of all employees working in the field of renewable energy worked in wind power, biomass and photovoltaic sectors $[4,5]$. In France, in addition to nuclear energy, priority renewable energy sources include wind and solar resources, the development of which seems to be the most promising [6,7]. Spain has one of the largest installed wind power capacities in the world [8,9]. The Swedish government's goal is to produce $100 \%$ renewable electricity by 2040 using currently dominant hydropower combined with wind power capacity $[10,11]$. The combination of wind power with hydropower, solar energy and biomass energy is the main renewable energy source in Poland [12,13]. Finland has a long tradition of using forest biomass for combined heat and power and heat production, but the use of other renewable energy sources, such as wind energy, liquid biofuels and heat pumps, will increase in the future $[14,15]$. Reducing the use of fossil fuels in Germany focuses on several types of renewables, with an emphasis on the use of solar, wind, biomass, hydropower and geothermal energy. The national German Energiewende program "from fossil fuels to renewables" pays great attention to energy storage in special batteries and ultra-capacitors, which are characterized by high energy density [16-18]. By using ultra-capacitors, it is possible to meet peak energy needs much more efficiently, to reduce the impact of long-term disturbances of wind or solar energy, to increase the flexibility of energy infrastructure (grids, pipelines and storage places), to coordinate energy resource management and optimal usage. In Denmark, electricity produced wind power will remain the cornerstone of the energy system [19-21]. Furthermore, a sustainable energy sector is inconceivable without thermal energy and electricity produced from renewable sources. Priority is given here to energy from sea waves and photovoltaics power generation. There is also a strong focus on fuel production from biomass. The growth of the Dutch economy is also linked to the use of renewable energy sources. Their expansion is projected to create over 50,000 new jobs by 2030 , and more than half of gas-fired power plants and fossil coal as a fuel will be replaced by solar panels and wind turbines, reaching $75 \%$ of electricity generation by 2030 from renewable sources [22]. In addition, much attention is and will be paid to the use of urban bio-waste in the electricity and especially thermal energy production sector [23].

\section{Renewable Energy}

Promoting the use of renewable energy sources (RES) has become an important option in tackling the energy crisis and environmental problems in many countries. Ensuring the sustainable development of renewable energy requires appropriate policy and strategic solutions to reduce greenhouse gas emissions and increase energy efficiency. Figure 1 shows the framework of "green" initiatives to maintain a balance between renewable energy sources, the environment and economic activity.

Globally, renewable energy sources include wind, solar, biomass, geothermal, biogas, tides and ocean and hydrogen energy (Figure 2).

Unfortunately, in the case of Lithuania, due to objective reasons, this list of potentially usable renewable energy sources is shortening, therefore we will review in detail only the most promising and relevant renewable energy sources for Lithuania.

\subsection{Wind Energy}

The use of wind energy has developed quite rapidly in many parts of the world over the last ten years. The total capacity of wind power industry has increased almost fivefold in the last ten years [24]. Compared to many new renewable energy sources, such as solar energy and biomass, the utilization costs of wind energy are relatively low. Analyzing the use of wind energy in Lithuania, it can be stated that in 2019, wind farms operating in Lithuania produced 1499.4 GWh of electricity, which is about $13 \%$ of the final electricity 
consumption in Lithuania [25]. In 2019, power plants using renewable energy sources in Lithuania produced 2469.1 GWh of electricity, most of which was generated by wind power plants (Figure 3).

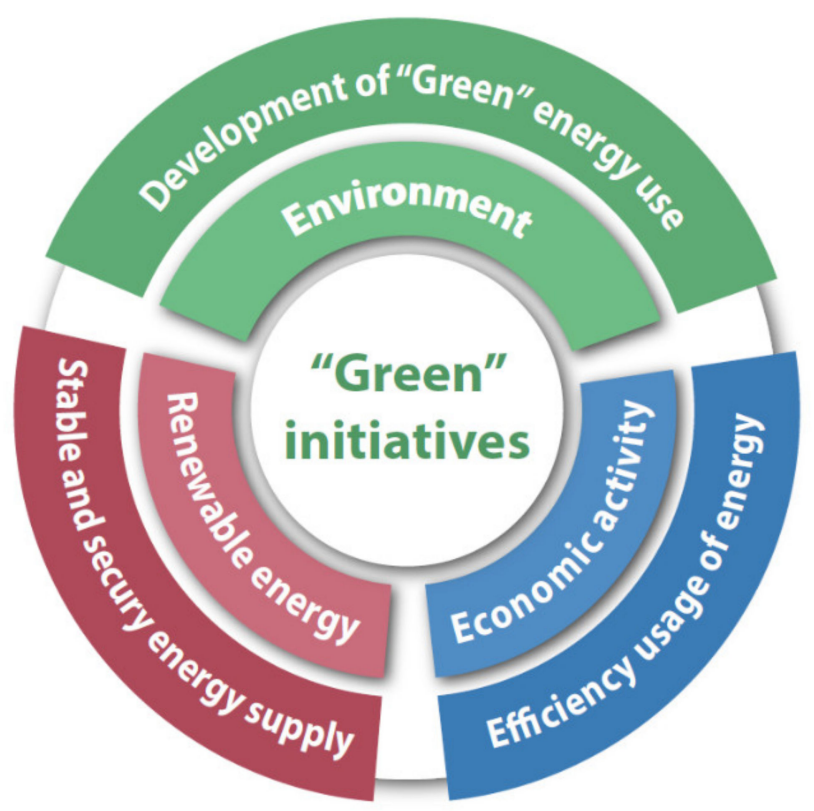

Figure 1. Framework of "Green" initiatives.

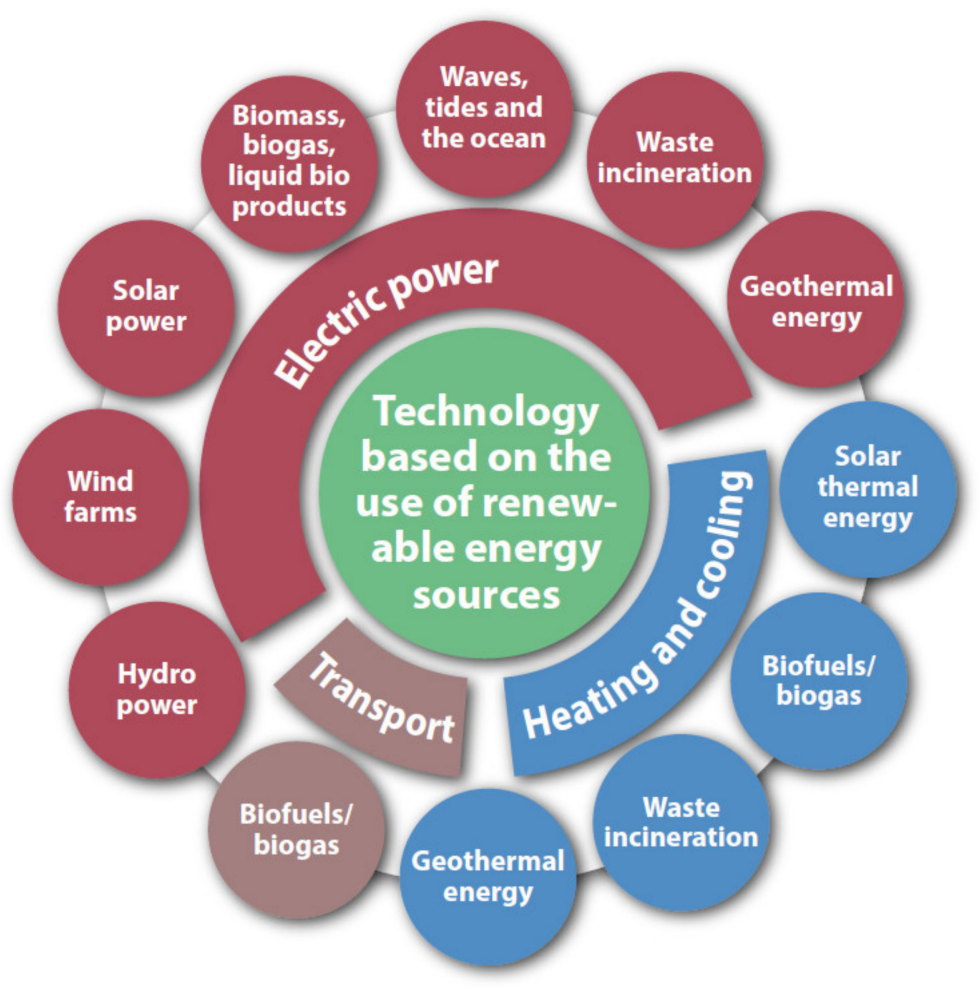

Figure 2. Technology based on the use of renewable energy sources. 


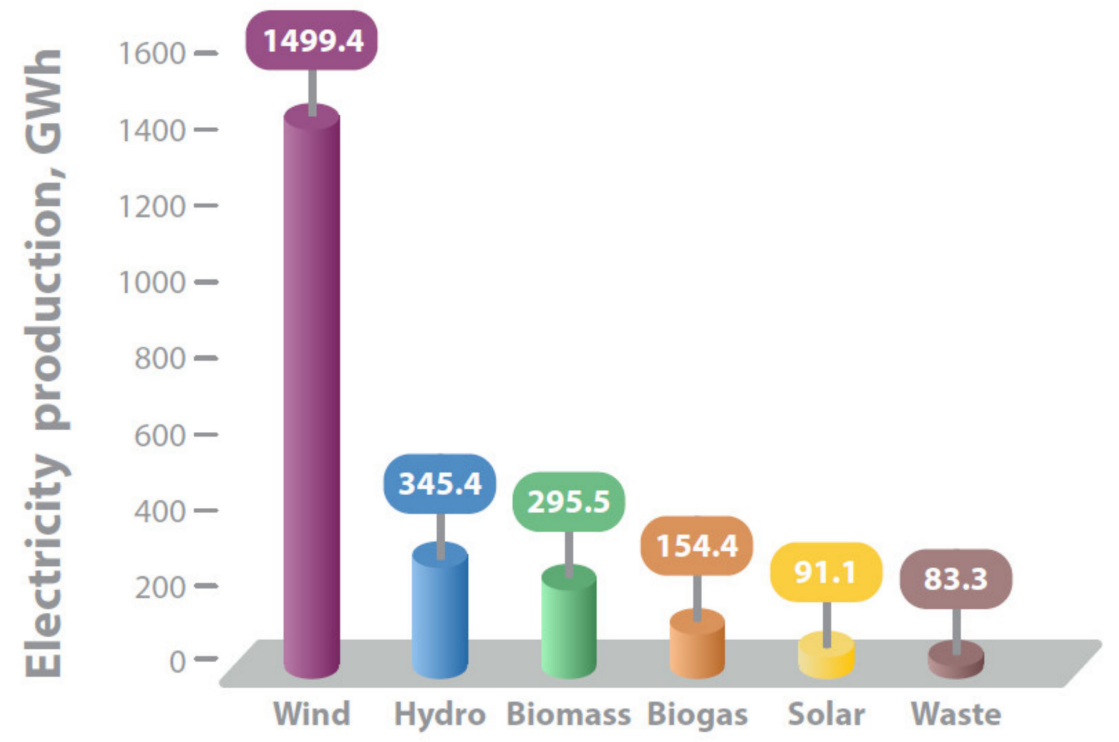

Figure 3. Electricity production from renewable energy sources in 2019.

According to the Lithuanian Wind Power Association, there are currently 23 wind farms with a capacity of $480 \mathrm{MW}$ in Lithuania, and a total of $546 \mathrm{MW}$ of power plants have been installed, including individual wind farms (Table 1), and this number is growing every year.

Table 1. Electricity capacity and generation $[25,26]$.

\begin{tabular}{ccc}
\hline Technology & Capacity in 2020, MW & \% \\
\hline Non-renewable & $\mathbf{2 4 9 3}$ & $\mathbf{7 3}$ \\
Renewable & $\mathbf{9 2 2}$ & $\mathbf{2 7}$ \\
Hydropower plants & 117 & 3.4 \\
Solar power plants & 148 & 4.3 \\
Wind farms & 539 & 15.8 \\
Bioenergy (biofuel, biogas) & 118 & 3.5 \\
power plants & 0 & 0 \\
Geothermal & $\mathbf{3 4 1 5}$ & $\mathbf{1 0 0}$ \\
Total & &
\end{tabular}

Electricity generated in wind farms accounts for more than a half of all electricity generated from renewable energy sources in Lithuania. Figure 4 shows the data of installed capacity of renewable energy power plants by source for 2020 .

Unfortunately, Lithuania still lags far behind countries such as Denmark, Ireland, Portugal and Germany in the use of wind energy, where according to the data of 2019, $48 \%, 33 \%, 27 \%$ and $26 \%$ of the country's electricity needs were produced, respectively. In addition, data from 2018 show that in Lithuania, the peak installed capacity, which describes the amount of electricity that the wind turbine can generate under optimal wind conditions, of $1 \mathrm{~kW}$ wind power plants produced an average of $2050 \mathrm{kWh}$ of electricity, while in all EU countries this total indicator is $3200 \mathrm{kWh} / \mathrm{kW}$. This means that a wind power plant of the same capacity in the EU produces on average 1.56 times more electricity than in Lithuania; at the same time - the cost of electricity produced by Lithuanian wind power plant is 1.56 times higher. Another important factor in the development of wind energy is the possibility of wind power plants to be connected to the electricity grid. Nevertheless, wind is currently the most efficient renewable resource. According to the goals set in the Lithuanian National Strategy, wind generation should triple by 2030, and in the long run, wind farms should produce more than $50 \%$ of Lithuania's electricity needs. 


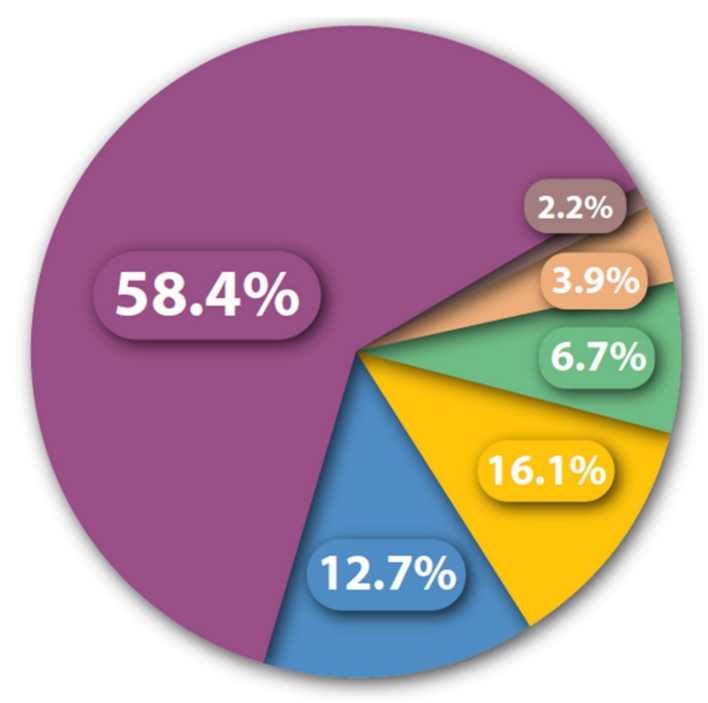

Figure 4. Installed capacity of power plants according to the renewable energy source in 2020.

Due to improving technologies, electricity is being extracted from wind energy more and more efficiently. According to the International Energy Agency, the price of electricity in onshore wind farms is about $\$ 50$ per megawatt-hour, compared to $\$ 80$ per megawatthour in 2012. The conditions for the development of wind energy in Lithuania are quite favorable, as there are plains and no natural barriers that can block the wind, but it should be noted that the average wind power is not the same every year and can vary by up to $20 \%$. There are certain obstacles to achieving the goals set in the National Energy Independence Strategy. One of the main obstacles is the cutting of incentives for larger wind farm projects. Another problem faced by project developers build new wind farms is related to the tax environment. In addition, the practice of municipalities to tax wind energy projects at the maximum property tax rate is controversial. Appropriate government assistance is needed to address these issues.

\subsection{Solar Energy}

The possibilities of using solar energy are very wide-it can be used for heating and lighting of residential and other buildings, for electricity generation, water heating, in agriculture, for charging electric cars, and for various economic, commercial and industrial needs. Part of the research aims to prove that solar energy is the most efficient renewable energy source for home and commercial use [27-30]. According to Solar Power European (SPE) statistics, in 2017, the total installed solar power capacity exceeded $400 \mathrm{GW}$ and increased by $32 \%$ compared to 2016 [24] and grew by $11 \%$ in 2020 . It is often assumed that there are very few solar energy resources in Lithuania, and that they are insignificant. However, comparing, for example, the number of sunny hours per year in Vilnius (1588 $\mathrm{h}$ per year) with the data for some European cities (Edinburg, there are $1427 \mathrm{~h}$ of sunshine per year, Dublin -1453, Brussels-1546, Zurich-1566, Warsaw-1571) we see that there are enough resources to use solar energy in both active and passive ways. The effect will certainly be lower than in countries such as Malta, Greece, Portugal, Spain or southern Italy, where the number of hours of sunshine per year is between 2400 and $2900 \mathrm{~h}$ of sunshine per year [31]. In recent years, Lithuania has seen an increase in the amount of energy generated by solar power plants. Solar power plants in 2019 produced 91.1 GWh of electricity, which is $34 \%$ more than in 2017 [25]. However, we should not forget the fact that solar power plants need about seven times more peak power than thermal power plants to produce the same amount of energy. In addition, research on the efficiency of innovation in the Lithuanian solar energy industry is currently relatively lacking.

Recently, however, the popularity of solar energy, especially in households, has been growing rapidly due to favorable government decisions. The legalization of remote solar 
power plants and the planned financial support for their installation paved the way for such a breakthrough. Efficient solutions for the interaction between solar power plants and geothermal heating are particularly popular among household owners. Residents who produce electricity from the sun pay less for it, and the increase in the number of consumers producing nationwide will have a tangible impact on the growth of Lithuania's energy independence. Solar power plants are predicted to continue to play a key role in the use of renewable energy sources in households in the future.

\subsection{Biomass Energy}

Biomass energy also successfully increases the share of Lithuania's renewable energy resources in the total state energy production balance. According to price and quality ratio and contribution to the energy balance, biofuels use has great potential in the future. Countries that are leaders in climate mitigation policies have already proven that biomass is a cornerstone for the world's transition to carbon-neutral energy in the future. Biomass for energy continues to be one of most important source of total production primary renewable energy in the EU, with a share of $58 \%$ in 2017 [32]. The uptake of renewable energy sources envisages increasing the efficiency of biomass energy production and the use of the obtained heat together with electricity in industry and for district heating, using both heat and electricity-producing cogeneration power plants. Sustainable forest management must be ensured here. It is required to ensure that no more biomass is harvested than replanted, that soil fertility and water quality are protected, and that the use of biomass would be closely linked to the protection of biodiversity. In addition, about half a million hectares of uncultivated land can be used for biomass cultivation. Unfortunately, biomass cultivation in Lithuania is developing very slowly.

In the production of fuels from biomass can be used miscellaneous wastes of organic origin. This is wood and its preparation and processing waste generated during the process, straw and oilseed rape, which is designated in agriculture as waste, stock-raising waste, organic waste, obtained in the food industry, selected organic waste from incoming municipal waste, organic substances accumulated in wastewater silt, etc. However, when burning more and more biomass, the environmental aspects of its use are becoming relevant. Despite the fact that biomass is a carbon-neutral renewable energy source, in addition to carbon dioxide, many toxic combustion products and particulate matter are released into the environment. Without taking in to account the specific properties of biomass, boilers and power plants using it can become sources of higher pollution instead of reducing emissions. It is therefore necessary to take measures to reduce polluting emissions by promoting the use biomass as a fuel. Despite a relatively small share of the total energy balance, the household-utility sector still remains a relatively large source of environmental pollution. Although the average annual concentration of fine particulate matter (PM2.5) in 2017 ranged from $3 \mu \mathrm{g} / \mathrm{m}^{3}$ to $17 \mu \mathrm{g} / \mathrm{m}^{3}$ and did not exceed the established norm $\left(25 \mu \mathrm{g} / \mathrm{m}^{3}\right)$, in certain periods of the year in some regions it was higher than the World Health Organization recommended $-10 \mu \mathrm{g} / \mathrm{m}^{3}$. It is therefore important to provide support to the household-utility sector on the possibility of installing cost-effective and energy-efficient heating systems in the building and improving the energy efficiency of the building. Solar batteries, solar collectors, geothermal heating not only free from the hassle of taking care of fuel, but also completely protect from indoor and ambient air pollution and its possible harmful effects on health.

Despite the current problems with the use of renewable energy sources, research confirms that renewable energy has a negative impact on $\mathrm{CO}_{2}$ emissions on a global scale [33]. It can be said that renewable energy is the most common an important solution for reducing $\mathrm{CO}_{2}$ emissions, as renewable energy plants emit the least $\mathrm{CO}_{2}$ of all power plants.

\subsection{Geothermal Energy}

In 2020, European geothermal electricity generation capacity reached 3.5 GWe. The number of operating plants is projected to double over the next 5-8 years [34]. In Lithuania, 
as in the whole world, geothermal energy resources extraction may be associated with hot dry rocks (using the heat of surface soil and bedrock), hot groundwater and low temperature groundwater $\left(<20^{\circ} \mathrm{C}\right)$. Of the renewable energy sources, geothermal energy is used the least in Lithuania so far and Lithuania lags far behind the EU average. Although these resources are renewable and inexhaustible, their use is limited by the fact that these resources are not available in all areas of Lithuania, requiring significant investment in technology and equipment (the main part of the costs consists of drilling deep wells). In addition, the extraction of this energy is limited by technical problems related to the operation of power plants. However, with the rapid development of technology, new regions, previously considered unviable, are beginning to be absorbed. Until ten years ago, the economic limit of geothermal electricity production was linked to a temperature of $200{ }^{\circ} \mathrm{C}$. Now this cartel has been lowered to $120-150^{\circ} \mathrm{C}$, and some geothermal power plants in the world already uses reservoirs with a temperature of only $100{ }^{\circ} \mathrm{C}$ [35]. Therefore, the possibilities to establish geothermal power plants in Lithuania are becoming a reality and should not be postponed to a long-term perspective.

\subsection{Hydropower Energy}

As mentioned earlier, the situation in Lithuania is not favorable for the development of hydropower energy. Moreover, energy produced in hydroelectric power stations on the plains cannot be considered as ecological. In addition to large floodplains, destroyed agricultural land and forests, and their biodiversity, hydroelectric ponds emit gases that cause global warming. Although the amount of these gases is relatively lower than in the case of thermal power plants, it accounts for a quarter of the greenhouse gas emissions of a gas-fired thermal power plant of analogous capacity. Increasing the development of hydropower plants would irreversibly destroy most of the remaining natural rivers in Lithuania, radically change the landscape, and lose unique habitats, forests, meadows and agricultural land.

\subsection{Hydrogen Energy}

Recently, there has been an increasing focus on hydrogen energy technologies. Unlike petrol or diesel, hydrogen combustion generates water vapor and does not emit greenhouse gases. For this reason, hydrogen technologies are considered promising in the search for alternative energy sources that can replace fossil fuels and do not contribute to climate change. Recently, however, most of the hydrogen has been produced from natural gas. This process is quite polluting because it results in the formation of greenhouse gas methane. The focus here must be on the production of clean hydrogen by electrolysis of water using only renewable energy sources, such as solar or wind energy $[19,36,37]$. Hydrogen technologies currently used in the EU account for a small share of total energy consumption, but the European Commission expects this share to rise to $14 \%$ by 2050 [38,39]. In order to exploit the potential of hydrogen energy in Lithuania, it is necessary to mobilize both the investment and legal environment, as well as market opportunities and scientific potential.

\section{Energy Efficiency}

Energy efficiency is one of the key factors in climate change mitigation strategies, improving energy security and ensuring environmental sustainability. As greenhouse gases are mainly generated by energy production and use, energy efficiency can have a significant impact on reducing greenhouse gas emissions. In addition, the need for energy investment and energy imports is declining, saving consumers money. Energy efficiency is described as the fastest and cheapest way to ensure security of energy supply and address environmental and economic challenges. That is why EU legislation has introduced measures for a number of greenhouse gas emitting sectors, and the EU itself has set energy efficiency targets for 2030. The European Union has set itself the goal of improving energy efficiency at the EU level by at least $32.5 \%$ by 2030 , while Lithuania has an obligation to save at least the total amount of final energy from 1 January 2021 to 
31 December 2030, which corresponds to 27.2792 TWh. In accordance with the law of the Republic of Lithuania on improving energy efficiency, the responsibilities of the Lithuanian ministries to achieve the set goal are shown in Figure 5.

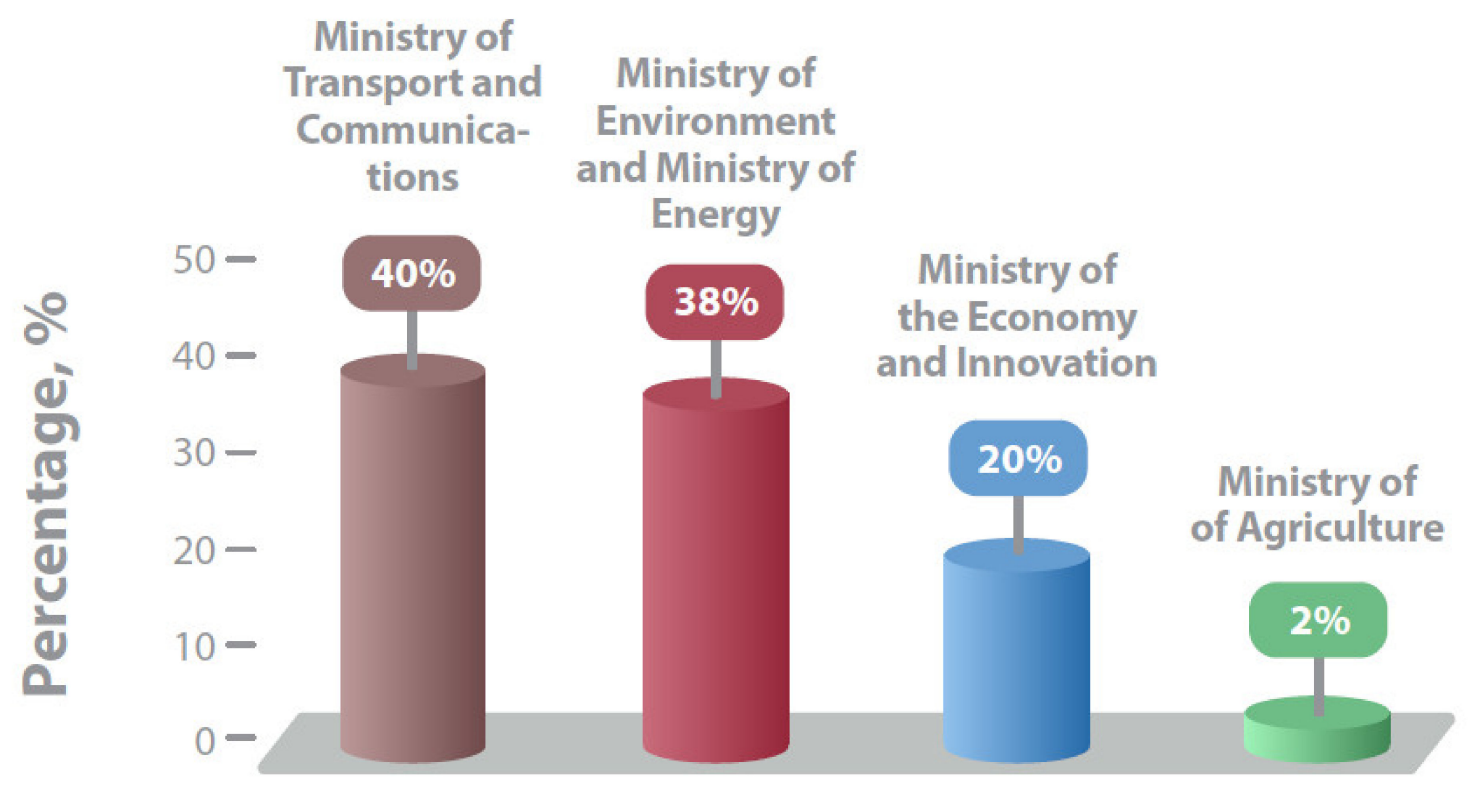

Figure 5. Obligations to save energy distribution between ministries (from 1 January 2021 to 31 December 2030).

The main energy efficiency measures planned to achieve the set goals by 2030 are the following: increasing energy efficiency in enterprises (projected energy savings of $1.1 \mathrm{TWh}$ ); railway electrification (projected energy savings $3.36 \mathrm{TWh}$ ); implementation of sustainable urban mobility plans (projected energy savings of $2.95 \mathrm{TWh}$ ); promotion of electric vehicles (projected energy savings of $6 \mathrm{TWh}$ ) and others (Figure 6).

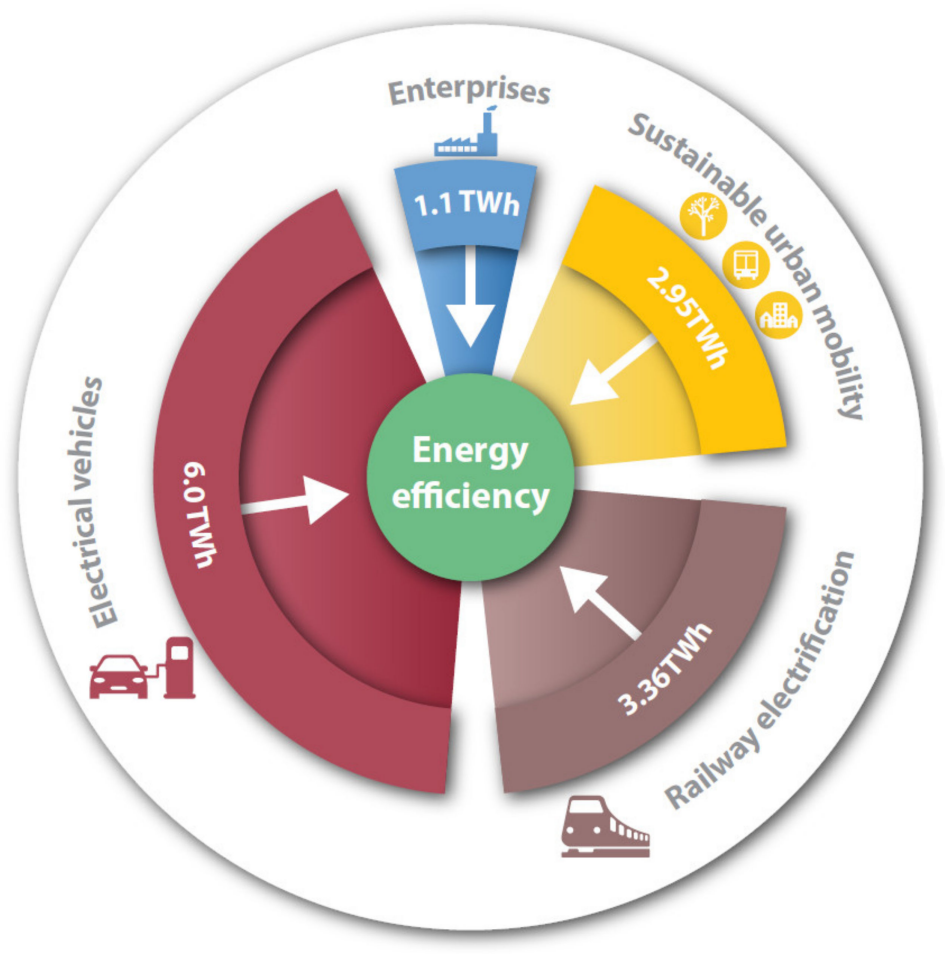

Figure 6. The main measures envisaged for energy efficiency. 
EU Member States are encouraged to prioritize energy efficiency policies aimed at reducing dependence on energy imports, reducing emissions and reducing energy bills. Renewable energy production contributes to mitigating climate change and increases countries' security of energy supply by reducing import dependence. An approach to reducing emissions based on technological innovation and energy efficiency is very important for the manufacturing industry, as relatively high energy consumption in the case of low efficiency is one of the main source damaging the environment [40]. Here, it is essential to make the right decisions, both legal and economic, to encourage industry to invest in energy-saving and emission-reducing technologies and, ultimately, to reduce carbon emissions. Energy technology innovation is closely linked to energy efficiency and renewable energy sources, while the impact of energy innovation and some forms of renewable energy sources on carbon emissions is still underestimated. It is important to mention that in 2015 the Energy Efficiency Fund, financed by the European Regional Development Fund, was established by a tripartite agreement between the Ministry of Finance, the Ministry of Energy of the Republic of Lithuania and the Public Investment Development Agency. Lithuania, in compliance with the provisions of its energy strategy and international obligations, is developing and improving the legal framework that would promote sustainable energy development. The projected changes in energy consumption by 2030 due to the efficient use of energy resources are presented in Figure 7.

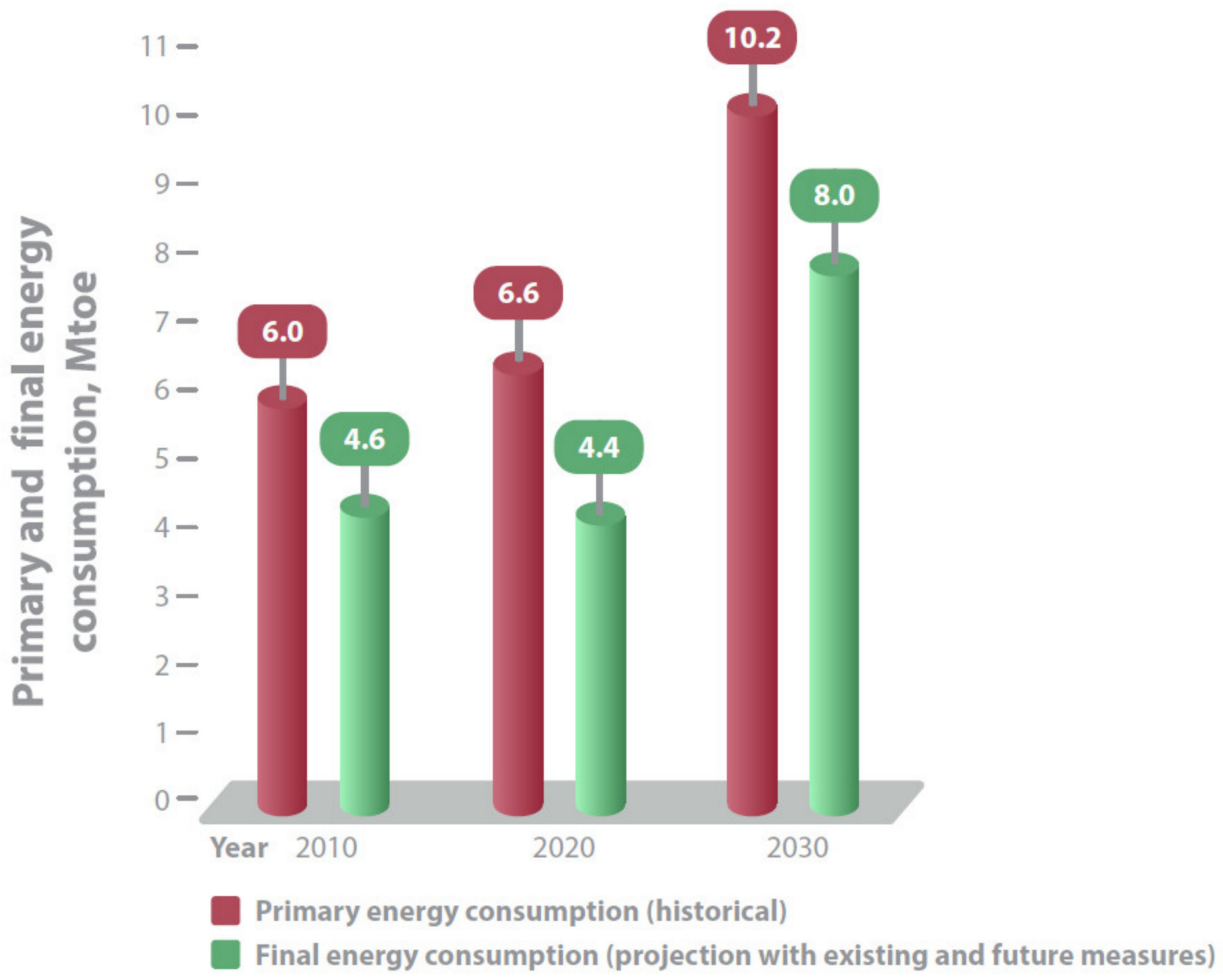

Figure 7. Energy efficiency: primary and final energy consumption.

The main measures in increasing the efficiency of energy use and reducing pollution in the most important sectors of the Lithuanian economy would be the following (Table 2).

In addition, municipal decisions play an important role in reducing pollution and promoting energy efficiency. Long-term planning decisions should be based on an assessment of future climate scenarios and the threats posed by climate change, with a particular focus on predictable extreme events (rains, heat waves, floods, droughts, forest fires, etc.) [41]. 
Table 2. Main measures in increasing the efficiency of energy use and reducing pollution in the sectors of the Lithuanian economy.

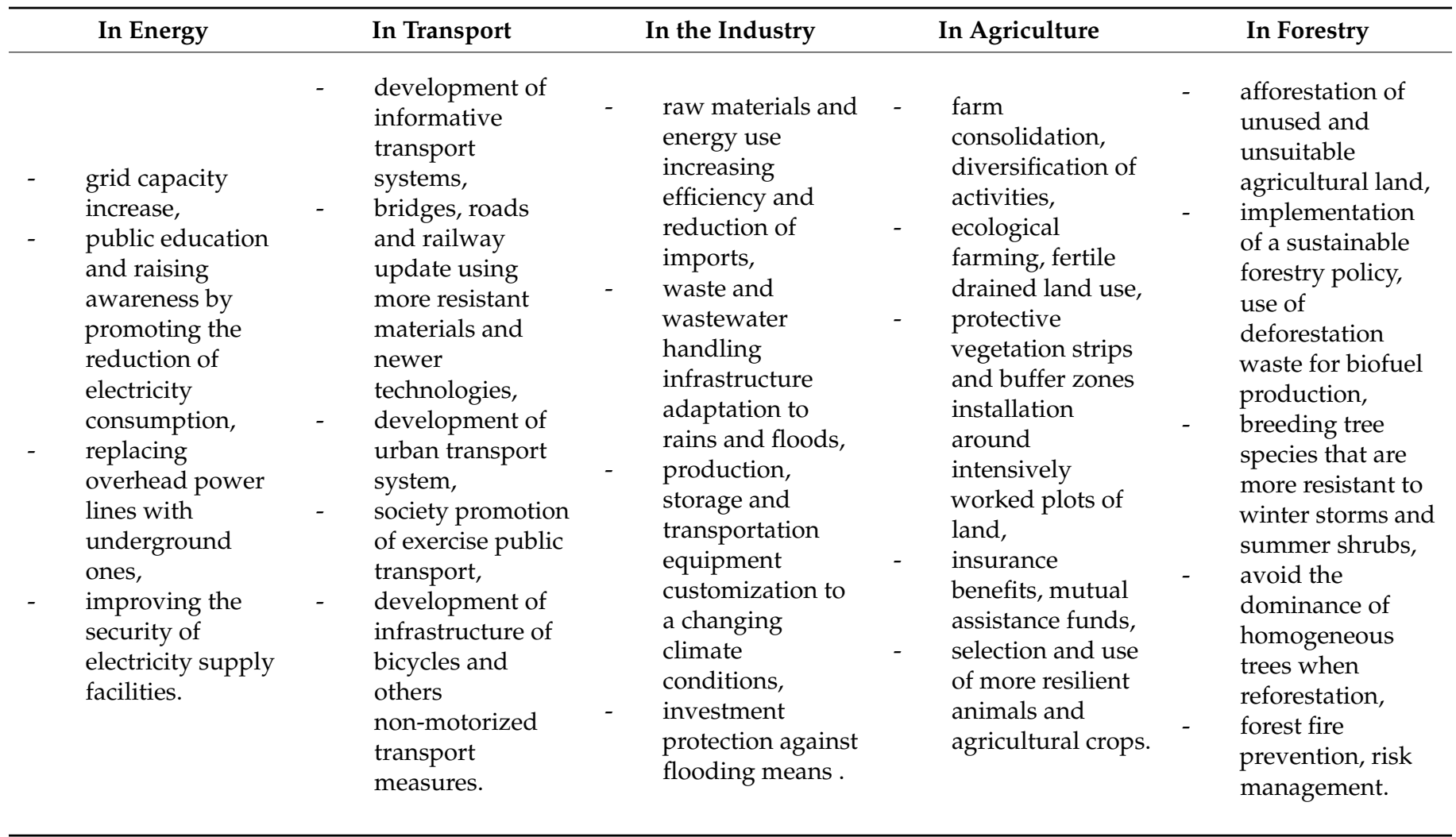

\section{Greenhouse Gas Emissions}

The biggest impact on the greenhouse effect is made by carbon dioxide, methane, nitrous oxide and fluorinated gases (F-gases). According to the United States Environmental Protection Agency, the percentage distribution of these greenhouse gases in 2019 was as follows: carbon dioxide $-80 \%$, methane $-10 \%$, nitrous oxide $-7 \%$, and various fluorine gases-3\% [42]. Most carbon dioxide is emitted by burning coal, oil products, natural gas, solid waste and as a result of certain chemical reactions, e.g., cement manufacture. The main sources of methane are coal, natural gas, oil production and transportation. Methane emissions also result from agricultural practices and the decomposition of organic waste in landfills for municipal solid waste. Nitrous oxide and fluorinated gases are typically emitted in smaller quantities during a variety of industrial and agricultural activities. Unfortunately, F-gases is the fastest growing class of greenhouse gases in the world, especially in developing countries [43-45].

A few years ago, together with the EU, Lithuania aims to reduce its total greenhouse gas emissions (GHG) up to 40\% by 2030 compared to 1990 levels, by 2040 reduce up to $60 \%$, and by 2050 reduce up to 80\% [2], but for the new European Commission, which took office in autumn 2019, such ambitions proved too weak and in 2020 it was decided to reduce $\mathrm{CO}_{2}$ by $60 \%$ by 2030 and make Europe a climate-neutral continent by 2050 . The implementation of such plans depends to a large extent on the expected funding from EU and national sources, so the package of possible measures to achieve the final goal is not entirely clear. Similar carbon reduction targets have been set by China, because the Chinese government also committed in the Paris Agreement that by 2030 China's carbon dioxide emissions per unit of GDP will fall by 60-65\% compared to 2005 [46-48]. Lithuanian industrial and energy companies participating in the EU Emissions Trading System (ETS) together with operators of other EU Member States must reduce their greenhouse gas emissions by a total of $43 \%$ compared to 2005 . Lithuania's GHG emission reduction target, which is not 
covered by the EU Emissions Trading System (non-ETS) by 2030, is -9\% compared to 2005, as set out in the Effort Sharing Regulation (ESR) [49]. Figure 8 shows the gaps between projected emissions and ESR targets for 2030.

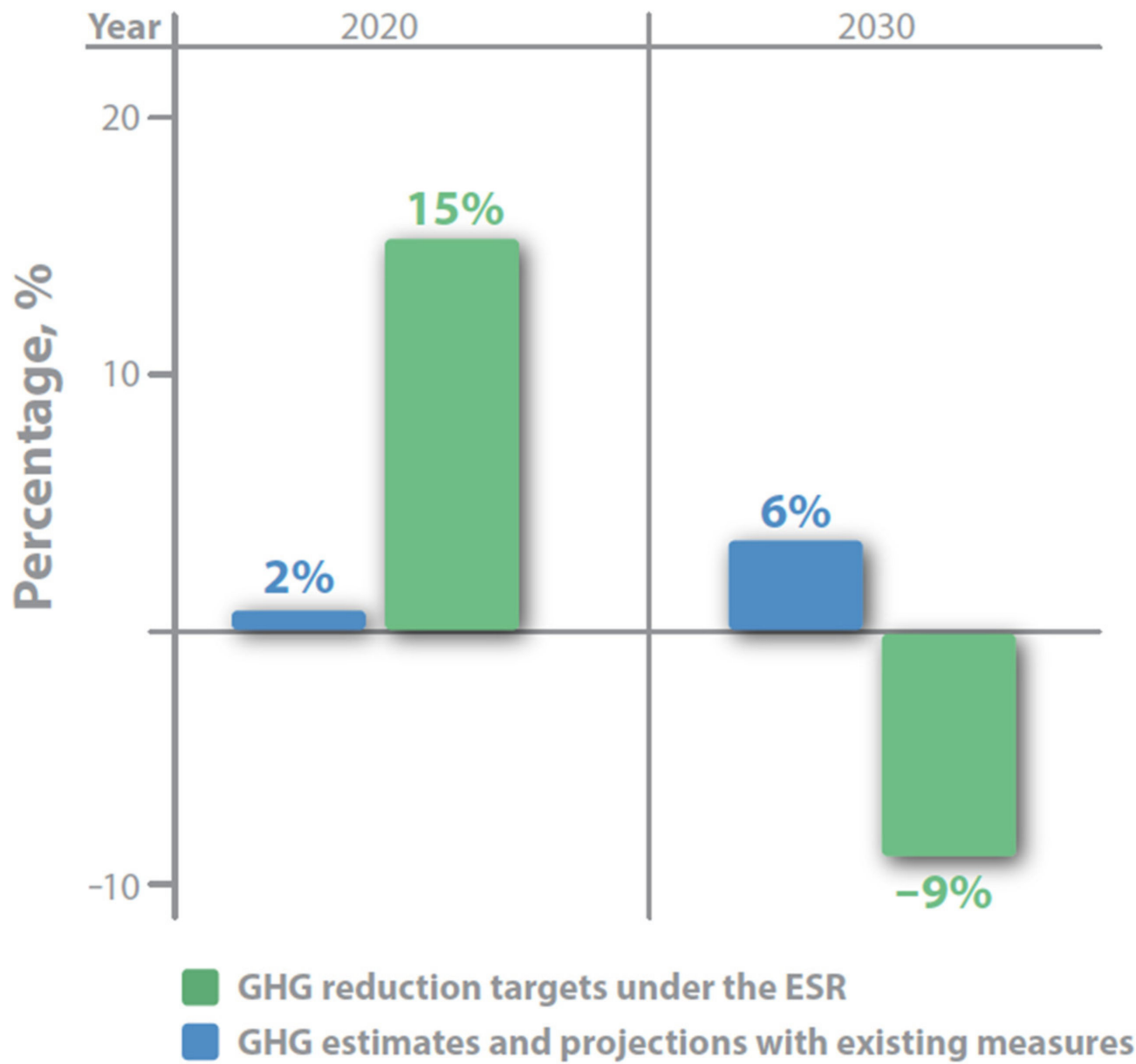

Figure 8. GHG emission targets for Lithuania by ESR, \%.

At the same time, Latvia needs to reduce its greenhouse gas emissions in the non-ETS sector by $6 \%$, Poland by 7\%, and Estonia by $13 \%$ until 2030 in comparison to 2005 [50-52]. National emission reduction targets are set on the basis of the principles of fairness, solidarity, cost-effectiveness and environmental benefits. Given the different capacities of the Member States to take action, the regulation differentiates the objectives according to the share of GDP per capita.

The strategic direction of Lithuania's climate change mitigation is to achieve that the country's economy grows faster than the amount of greenhouse gas emissions increases. The most significant source of GHG in 2019 was carbon dioxide, which accounted for $68.4 \%$ of the country's total greenhouse gas emissions, expressed in $\mathrm{CO}_{2}$ equivalent [53]. This was followed by methane (14.5\%) and nitrous oxide (14.3\%). Meanwhile, hydrofluorocarbons, nitrogen trifluoride and sulphur hexafluoride together accounted for only $2.8 \%$ of total GHG emissions in Lithuania (Figure 9).

In 2019, 20.37 million tons of total GHG were emitted into the atmosphere in Lithuania. The largest source of GHG generation is the energy sector, which is dominated both in the general context of all emissions and in $\mathrm{CO}_{2}$ emissions, which in 2019 accounted for $58.4 \%$ of the total emissions and $80.7 \%$ of the total national $\mathrm{CO}_{2}$ emissions (excluding land use, land-use change and forestry), in 2019 [54]. The main sectors here are transport and the energy industries, which generated $52.9 \%$ and $19.2 \%$ of the total $\mathrm{CO}_{2}$ emissions in energy section, respectively, in 2019. The second and third most important sources of GHG 
emissions are the agricultural sector, which accounts for $20.9 \%$ of the total national GHG emission and industrial processes and product use sector, which accounted for $16.7 \%$ of total national GHG emissions. In the agricultural sector, the most significant sources in 2019 were methane and nitrous oxides emissions, while in the industrial processes and product use sector, the largest emissions were accounted for by ammonia production, nitric acid production and cement production $[55,56]$. The waste sector accounts for a relatively small share of the total $\mathrm{CO}_{2}$ emissions (Figure 10).

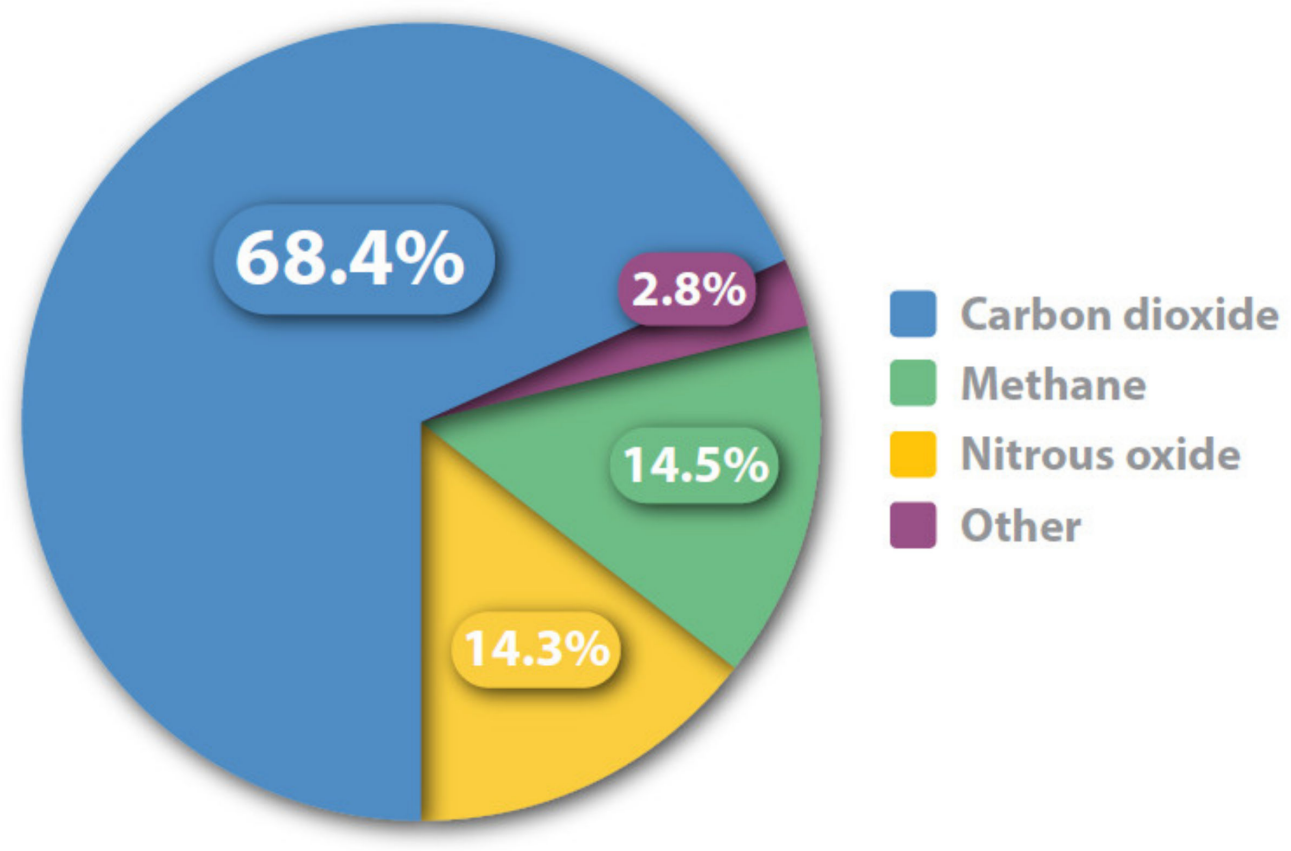

Figure 9. Lithuanian greenhouse gas emissions by gas in 2019.

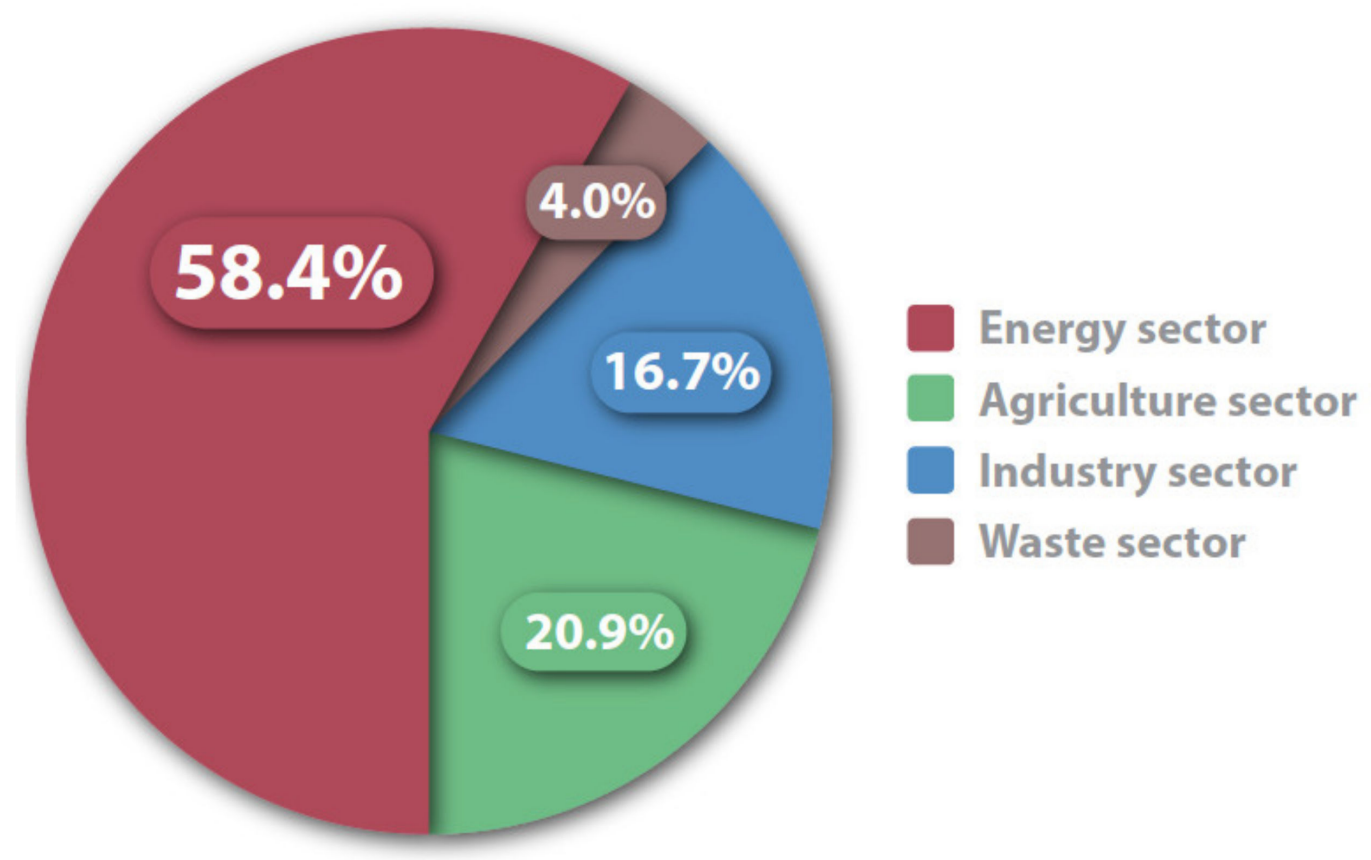

Figure 10. Lithuanian greenhouse gas emissions by economic sector in 2019.

Past statistics show that between 1990 and 2000, GHG emissions fell sharply as a result of declining industrial production (Figure 11). 


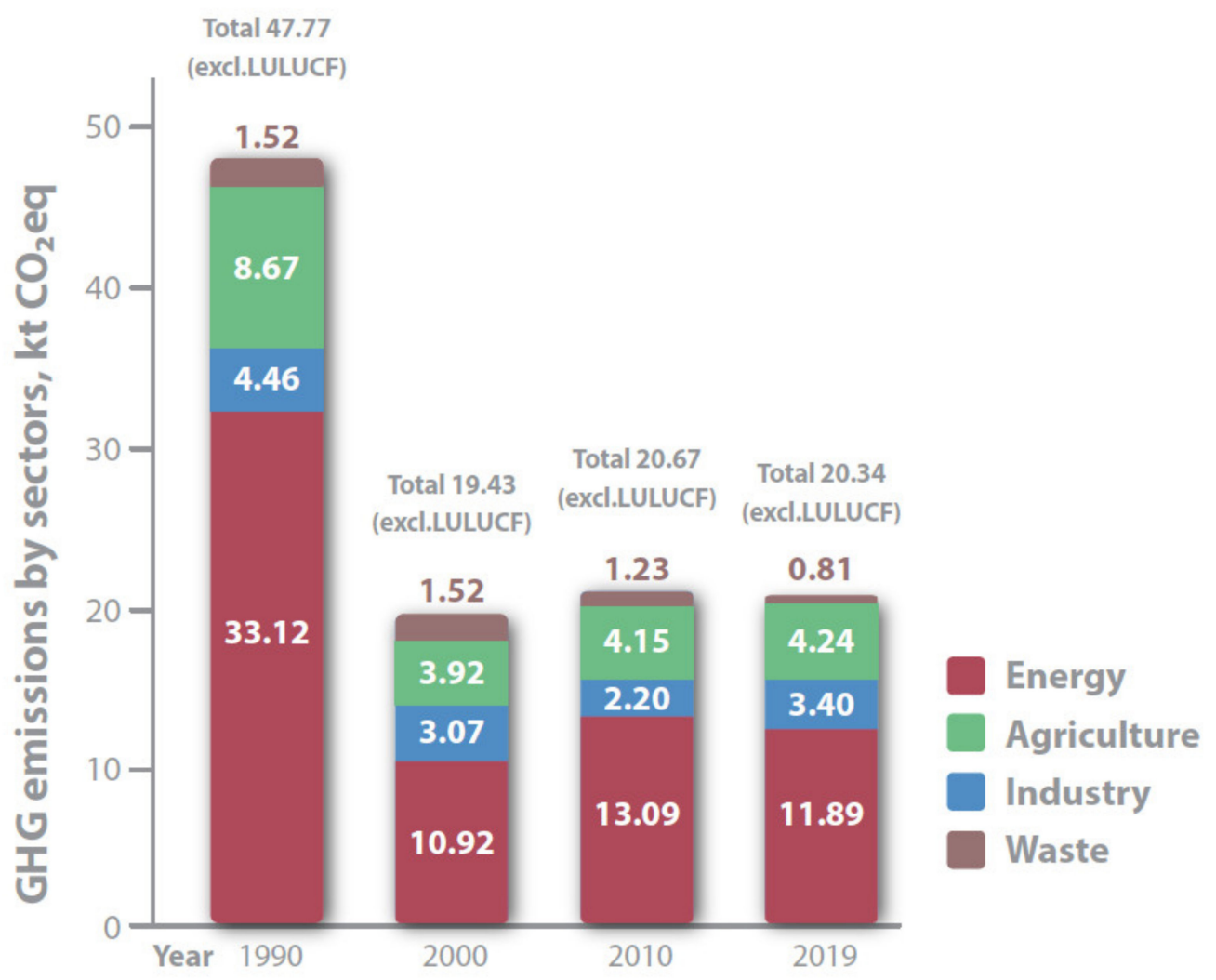

Figure 11. Lithuanian GHG emissions by sectors during the period from 1990 to 2019 , $\mathrm{kt}^{\mathrm{CO}_{2}}$ eq.

When the economy started to grow again, emissions increased, but slightly. This was mainly due to energy efficiency and other significant measures taken to reduce emissions [55]. Therefore, public authorities have a key role to play in promoting the renovation and modernization of public and residential buildings through energy efficiency measures to improve the energy performance of buildings, modernize urban street lighting systems, create a healthy urban ecosystem, increase water use efficiency, and legalize compulsory waste recycling $[56,57]$. There are already many technological solutions that help reduce energy costs: heat pumps, wind turbines, solar collectors, recuperative air conditioning systems and so on. In addition, compared to other countries that are most advanced in the use of renewable energy sources, Lithuania still does not have sufficient measures to promote the use of renewable energy. The attitude of every member in society towards waste sorting, the choice of a less polluting vehicle, the choice of alternative energy systems in the household, the overall reduction of energy consumption, the use of green electricity produced from renewable energy sources, becomes a very important factor here. It is important to educate the population and explain how an insulated home, an economical light bulb, an economical heating or water supply system will save energy and money.

\section{Conclusions}

The level of carbon dioxide in the atmosphere is already such that climate change cannot be stopped by reducing $\mathrm{CO}_{2}$ emissions alone. Although $\mathrm{CO}_{2}$ is the main concern at the moment, mainly from fossil fuel combustion, methane gas could become no less important in the near future due to the so-called positive feedback loop: global warming is melting the perennial Arctic frost, releasing methane into the atmosphere and the climate continues to warm, so even more frost melts, more methane is formed, and so on. It is crucial to realize that the longer the postponement of climate change mitigation and adaptation measures, the more efforts will be needed in the future to reduce the negative impacts in all areas. Here, technological progress and the rapid uptake of new technologies are becoming a key factor in the sustainable development of the renewable energy industry. 
In order to promote "Green" initiatives, reduce $\mathrm{CO}_{2}$ emissions and to ensure a more even and efficient development of renewable energy sources, one of the measures would be continuous close cooperation between businesses operating in the field of renewable energy resources, municipal policymakers and scientific institutions, providing open access to technical-economic performance indicators. Effective energy use is one of the best ways to reduce emissions of greenhouse gases and other pollutants.

In line with the commitments made in the EU directives, Lithuanian government's strategy is based on the rapid expansion of renewable energy-related industries, while promoting job creation and implementing environmental and global warming mitigation solutions. As one of the most popular and important sources among renewable energy, wind energy, supported by government action, has been experiencing a huge explosion of growth in recent years and shows great potential for reducing emissions in the future. Biomass also has the largest energy future in Lithuania, from which biofuels are produced. Government policy has a major role to play here. The government should control the level of investment in the renewable energy industry, adjust investment in relevant industries, improve the efficiency of capital use. The government should influence policies such as taxation and interest rates, further improve financial subsidy policies related to modern technological innovation, improve differentiated incentive policies to assess the specific situation of a company, strengthen coordination and efficient use of resources between ministries and departments, and fully assess the impact of innovation synergies on enterprises. It is therefore essential to fully promote the use of renewable energy, to support voluntary environmental policies in industry and to increase energy efficiency through various measures. Businesses should be encouraged to develop and use "Green" technologies through tax incentives.

When replacing old energy sources with new ones, the government should be obliged to subsidize households to purchase energy-saving equipment.

It is very important to strengthen the already existing regional co-operation between Lithuania and the other Baltic States and Poland to expand it to new areas and to increase the geographical coverage to include the Nordic countries, which is especially important in ensuring energy security.

Author Contributions: Concept of research, S.B. and V.N.; methodology, S.B., Y.B.; validation, J.B.; visualization, J.B., S.B. and W.C.; investigation, S.B. and V.N.; resources, J.B. and S.B.; data curation, J.B., S.B. and V.N.; writing-original draft preparation, S.B.; supervision, V.N. and J.B.; writing-review and editing, S.B., V.N., Y.B., W.C. and J.B.; analyzed the data, S.B., Y.B., W.C. and V.N. All authors have read and agreed to the published version of the manuscript.

Funding: This research received no external funding.

Institutional Review Board Statement: Not applicable.

Informed Consent Statement: Not applicable.

Data Availability Statement: Not applicable.

Conflicts of Interest: The authors declare no conflict of interest.

\section{References}

1. OECD. OECD Economic Surveys: Lithuania 2020; OECD Publishing: Paris, France, 2020. [CrossRef]

2. Zhu, D.; Mortazavi, S.M.; Maleki, A.; Aslani, A.; Yousefi, H. Analysis of the robustness of energy supply in Japan: Role of renewable energy. Energy Rep. 2020, 6, 378-391. [CrossRef]

3. Nagatomo, Y.; Ozawa, A.; Kudoh, Y.; Hondo, H. Impacts of employment in power generation on renewable-based energy systems in Japan-Analysis using an energy system model. Energy 2021, 226, 120350. [CrossRef]

4. Zhen, W.; Xin-Gang, Z.; Ying, Z. Biased technological progress and total factor productivity growth: From the perspective of China's renewable energy industry. Renew. Sustain. Energy Rev. 2021, 146, 111136. [CrossRef]

5. Liu, X.; Zhao, T.; Chang, C.-T.; Fu, C.J. China's renewable energy strategy and industrial adjustment policy. Renew. Energy 2021, 170, 1382-1395. [CrossRef]

6. Cany, C.; Mansilla, C.; Mathonnière, G.; da Costa, P. Nuclear contribution to the penetration of variable renewable energy sources in a French decarbonised power mix. Energy 2018, 150, 544-555. [CrossRef] 
7. Roussafi, F. Regional development trajectories of renewable energy: Evidence from French regions. Energy Strat. Rev. 2021, 35, 100639. [CrossRef]

8. Marques, A.C.; Fuinhas, J.A.; Macedo, D. The impact of feed-in and capacity policies on electricity generation from renewable energy sources in Spain. Util. Policy 2019, 56, 159-168. [CrossRef]

9. Colmenar-Santos, A.; Perera-Perez, J.; Borge-Diez, D.; Depalacio-Rodríguez, C. Offshore wind energy: A review of the current status, challenges and future development in Spain. Renew. Sustain. Energy Rev. 2016, 64, 1-18. [CrossRef]

10. Zhong, J.; Bollen, M.; Rönnberg, S. Towards a 100\% renewable energy electricity generation system in Sweden. Renew. Energy 2021, 171, 812-824. [CrossRef]

11. Glaa, B.; Mignon, I. Identifying gaps and overlaps of intermediary support during the adoption of renewable energy technology in Sweden-A conceptual framework. J. Clean. Prod. 2020, 261, 121178. [CrossRef]

12. Igliński, B.; Iglińska, A.; Koziński, G.; Skrzatek, M.; Buczkowski, R. Wind energy in Poland-History, current state, surveys, Renewable Energy Sources Act, SWOT analysis. Renew. Sustain. Energy Rev. 2016, 64, 19-33. [CrossRef]

13. Hernik, J.; Noszczyk, T.; Rutkowska, A. Towards a better understanding of the variables that influence renewable energy sources in eastern Poland. J. Clean. Prod. 2019, 241, 118075. [CrossRef]

14. Holma, A.; Leskinen, P.; Myllyviita, T.; Manninen, K.; Sokka, L.; Sinkko, T.; Pasanen, K. Environmental impacts and risks of the national renewable energy targets-A review and a qualitative case study from Finland. Renew. Sustain. Energy Rev. 2018, 82, 1433-1441. [CrossRef]

15. Panula-Ontto, J.; Luukkanen, J.; Kaivo-Oja, J.; O’Mahony, T.; Vehmas, J.; Valkealahti, S.; Björkqvist, T.; Korpela, T.; Järventausta, P.; Majanne, Y.; et al. Cross-impact analysis of Finnish electricity system with increased renewables: Long-run energy policy challenges in balancing supply and consumption. Energy Policy 2018, 118, 504-513. [CrossRef]

16. Scholz, R.; Beckmann, M.; Pieper, C.; Muster, M.; Weber, R. Considerations on providing the energy needs using exclusively renewable sources: Energiewende in Germany. Renew. Sustain. Energy Rev. 2014, 35, 109-125. [CrossRef]

17. Kriechbaum, M.; Posch, A.; Hauswiesner, A. Hype cycles during socio-technical transitions: The dynamics of collective expectations about renewable energy in Germany. Res. Policy 2021, 50, 104262. [CrossRef]

18. Matschoss, P.; Bayer, B.; Thomas, H.; Marian, A. The German incentive regulation and its practical impact on the grid integration of renewable energy systems. Renew. Energy 2018, 134, 727-738. [CrossRef]

19. Berg, T.L.; Apostolou, D.; Enevoldsen, P. Analysis of the wind energy market in Denmark and future interactions with an emerging hydrogen market. Int. J. Hydrogen Energy 2020, 46, 146-156. [CrossRef]

20. Mortensen, A.W.; Mathiesen, B.V.; Hansen, A.B.; Pedersen, S.L.; Grandal, R.D.; Wenzel, H. The role of electrification and hydrogen in breaking the biomass bottleneck of the renewable energy system-A study on the Danish energy system. Appl. Energy 2020, 275,115331 . [CrossRef]

21. Johansen, K. Blowing in the wind: A brief history of wind energy and wind power technologies in Denmark. Energy Policy 2021, 152, 112139. [CrossRef]

22. Bulavskaya, T.; Reynès, F. Job creation and economic impact of renewable energy in the Netherlands. Renew. Energy 2018, 119, 528-538. [CrossRef]

23. Van Leeuwen, L.B.; Cappon, H.J.; Keesman, K.J. Urban bio-waste as a flexible source of electricity in a fully renewable energy system. Biomass Bioenergy 2021, 145, 105931. [CrossRef]

24. Li, L.; Lin, J.; Wu, N.; Xie, S.; Meng, C.; Zheng, Y.; Wang, X.; Zhao, Y. Review and outlook on the international renewable energy development. Energy Built Environ. 2020, in press. [CrossRef]

25. Official Statistics Portal of the Republic of Lithuania. Environment Protection and Energy. 2020. Available online: https: / / osp.stat.gov.lt/statistiniu-rodikliu-analize\#/ (accessed on 27 July 2021).

26. The International Renewable Energy Agency (IRENA). Renewable Energy Statistics 2021; The International Renewable Energy Agency: Abu Dhabi, United Arab Emirates, 2021; 460p.

27. Hamzaoğlu, A.; Erduman, A.; Alçı, M. Reduction of distribution system losses using solar energy cooperativity by home user. Ain Shams Eng. J. 2021, in press. [CrossRef]

28. Fraser, T. Does social capital boost or block renewable energy siting? South African solar politics in comparison. Energy Res. Soc. Sci. 2020, 71, 101845. [CrossRef]

29. Cousse, J. Still in love with solar energy? Installation size, affect, and the social acceptance of renewable energy technologies. Renew. Sustain. Energy Rev. 2021, 145, 111107. [CrossRef]

30. Gu, G.; Yang, D.; Feng, T.; Timmermans, H. Influence of the adoption of new mobility tools on investments in home renewable energy equipment: Results of a stated choice experiment. Sustain. Cities Soc. 2019, 50, 101641. [CrossRef]

31. Murray, E. World Cities Ranked by Annual Sunshine Hours. 2019. Available online: https://data.world/makeovermonday/2019 w44 (accessed on 14 July 2021).

32. Bioenergy in Europe. Overview. European Technology and Innovation Platform, Bioenergy Fact Sheet. 2020. Available online: https:/ / www.etipbioenergy.eu/images/ETIP_B_Factsheet_Bioenergy\%20in\%20Europe_rev_feb2020.pdf (accessed on 21 July 2021).

33. Shahnazi, R.; Shabani, Z.D. The effects of renewable energy, spatial spillover of $\mathrm{CO}_{2}$ emissions and economic freedom on $\mathrm{CO}_{2}$ emissions in the EU. Renew. Energy 2021, 169, 293-307. [CrossRef] 
34. Garabetian, T.; Dumas, P.; Serrano, C.; Mazzagatti, V.; Kumar, S.; Dimitrisina, R.; Erbanova, H.; Katechi, S. (Eds.) EGEC Geothermal Market Report. Key Findings, 10th ed.; European Geothermal Energy Council: Brussels, Belgium, 2021; 26p.

35. Buscheck, T.A.; Bielicki, J.; Randolph, J.B. $\mathrm{CO}_{2}$ Earth Storage: Enhanced Geothermal Energy and Water Recovery and Energy Storage. Energy Procedia 2017, 114, 6870-6879. [CrossRef]

36. Burton, N.; Padilla, R.; Rose, A.; Habibullah, H. Increasing the efficiency of hydrogen production from solar powered water electrolysis. Renew. Sustain. Energy Rev. 2020, 135, 110255. [CrossRef]

37. Ayodele, T.; Munda, J. Potential and economic viability of green hydrogen production by water electrolysis using wind energy resources in South Africa. Int. J. Hydrogen Energy 2019, 44, 17669-17687. [CrossRef]

38. Kakoulaki, G.; Kougias, I.; Taylor, N.; Dolci, F.; Moya, J.; Jäger-Waldau, A. Green hydrogen in Europe-A regional assessment: Substituting existing production with electrolysis powered by renewables. Energy Convers. Manag. 2020, 228, 113649. [CrossRef]

39. Lux, B.; Pfluger, B. A supply curve of electricity-based hydrogen in a decarbonized European energy system in 2050. Appl. Energy 2020, 269, 115011. [CrossRef]

40. Cai, W.; Lai, K.-H.; Liu, C.; Wei, F.; Ma, M.; Jia, S.; Jiang, Z.; Lv, L. Promoting sustainability of manufacturing industry through the lean energy-saving and emission-reduction strategy. Sci. Total Environ. 2019, 665, 23-32. [CrossRef]

41. Kilpys, J.; Pauša, K.; Jurkus, N. Climate Change Mitigation and Adaptation Climate Change Guidelines for Municipalities; Lithuanian Association of Municipalities: Vilnius, Lithuania, 2017; 73p, Available online: https:/ /www.krea.lt/images/angle180/klimatokaita-gaires-savivaldybems.pdf (accessed on 6 June 2021). (In Lithuanian)

42. U.S. EPA. Inventory of U.S. Greenhouse Gas Emissions and Sinks. 1990-2019. 2021. Available online: https://www.epa.gov/ ghgemissions/inventory-us-greenhouse-gas-emissions-and-sinks (accessed on 6 July 2021).

43. Sovacool, B.K.; Griffiths, S.; Kim, J.; Bazilian, M. Climate change and industrial F-gases: A critical and systematic review of developments, sociotechnical systems and policy options for reducing synthetic greenhouse gas emissions. Renew. Sustain. Energy Rev. 2021, 141, 110759. [CrossRef]

44. Lindley, A.; McCulloch, A. Regulating to reduce emissions of fluorinated greenhouse gases. J. Fluor. Chem. 2005, 126, 1457-1462. [CrossRef]

45. Bronson, K.; Hunsaker, D.; El-Shikha, D.; Rockholt, S.; Williams, C.; Rasutis, D.; Soratana, K.; Venterea, R. Nitrous oxide emissions, $\mathrm{N}$ uptake, biomass, and rubber yield in N-fertilized, surface-irrigated guayule. Ind. Crop. Prod. 2021, 167, 113561. [CrossRef]

46. Sun, J.; Du, T.; Sun, W.; Na, H.; He, J.; Qiu, Z.; Yuan, Y.; Li, Y. An evaluation of greenhouse gas emission efficiency in China's industry based on SFA. Sci. Total Environ. 2019, 690, 1190-1202. [CrossRef]

47. Mao, W.; Wang, W.; Sun, H. Driving patterns of industrial green transformation: A multiple regions case learning from China. Sci. Total Environ. 2019, 697, 134134. [CrossRef]

48. Xia, F.; Zhang, X.; Cai, T.; Wu, S.; Zhao, D. Identification of key industries of industrial sector with energy-related $\mathrm{CO}_{2}$ emissions and analysis of their potential for energy conservation and emission reduction in Xinjiang, China. Sci. Total Environ. 2019, 708, 134587. [CrossRef]

49. The European Parliament; the Council of the European Union. Regulation (EU) 2018/842 of the European Parliament and of the Council of 30 May 2018 on binding annual greenhouse gas emission reductions by Member States from 2021 to 2030 contributing to climate action to meet commitments under the Paris Agreement and amending Regulation (EU) No 525/2013. Off. J. Eur. Union 2018, 61, 156. Available online: http:/ / data.europa.eu/eli/reg/2018/842/oj (accessed on 27 July 2021).

50. Matiiuk, Y.; Poškus, M.S.; Liobikienè, G. The Implementation of Climate Change Policy in Post-Soviet Countries Achieving Long-Term Targets. Sustainability 2020, 12, 4558. [CrossRef]

51. Cilinskis, E.; Ziemele, J.; Blumberga, A.; Blumberga, D. Analysis of support measures for promoting energy efficiency and renewables for GHG emissions reduction in non-ETS sector. Energy Procedia 2017, 142, 2838-2843. [CrossRef]

52. Lithuania's National Inventory Report 2021. Greenhouse Gas Emissions 1990-2019. 2021; 566p, Available online: https: / / unfccc.int/sites/default/files/resource/ltu-2021-nir-15apr21.zip (accessed on 19 June 2021).

53. Sansyzbayeva, G.; Temerbulatova, Z.; Aknur, Z.; Ashirbekova, L. Evaluating the transition to green economy in Kazakhstan: A synthetic control approach. J. Int. Stud. 2020, 13, 324-341. [CrossRef] [PubMed]

54. Hnatyshyn, M. Decomposition analysis of the impact of economic growth on ammonia and nitrogen oxides emissions in the European Union. J. Int. Stud. 2018, 11, 201-209. [CrossRef] [PubMed]

55. Tvaronavičienė, M.; Prakapienè, D.; Garškaitè-Milvydienè, K.; Prakapas, R.; Nawrot, Ł. Energy Efficiency in the Long-Run in the Selected European Countries. Econ. Sociol. 2018, 11, 245-254. [CrossRef]

56. Svazas, M.; Navickas, V.; Krajnakova, E.; Nakonieczny, J. Sustainable supply chain of the biomass cluster as a factor for preservation and enhancement of forests. J. Int. Stud. 2019, 12, 309-321. [CrossRef]

57. Glavič, P. Evolution and Current Challenges of Sustainable Consumption and Production. Sustainability 2021, 13, 9379. [CrossRef] 